University of Nebraska - Lincoln

DigitalCommons@University of Nebraska - Lincoln

Journal of Women in Educational Leadership

Educational Administration, Department of

$2-2022$

\title{
The Life of Ruth Bader Ginsberg: Biography of an Educator
}

Mallory Wallace

University of Nebraska-Lincoln, mallory@unl.edu

Follow this and additional works at: https://digitalcommons.unl.edu/jwel

Part of the Educational Administration and Supervision Commons, Educational Leadership Commons, and the Judges Commons

Wallace, Mallory, "The Life of Ruth Bader Ginsberg: Biography of an Educator" (2022). Journal of Women in Educational Leadership. 280.

https://digitalcommons.unl.edu/jwel/280

This Article is brought to you for free and open access by the Educational Administration, Department of at DigitalCommons@University of Nebraska - Lincoln. It has been accepted for inclusion in Journal of Women in Educational Leadership by an authorized administrator of DigitalCommons@University of Nebraska - Lincoln. 


\title{
The Life of Ruth Bader Ginsberg: Biography of an Educator
}

\author{
Mallory Wallace \\ University of Nebraska-Lincoln
}

Now in her eighties, U.S. Supreme Court Justice Ruth Bader Ginsburg has lived a remarkable life. She has spent almost three decades on the Supreme Court as an Associate Justice, previously spending 13 years on the United States Court of Appeals for the District of Columbia Circuit ("Justice Ruth Bader...", 1997). Her professional activities include time as law clerk and as general counsel for and co-founder of the American Civil Liberties Union (ACLU) Women's Rights Project, positions on the American Bar Association (ABA) Board of Directors, the American Law Institute, the American Academy of Arts and Sciences, and the Council on Foreign Relations ("Justice Ruth Bader...", 1997). Justice Ginsburg has had an enormous impact on the way United States law respects gender equality, transformed the U.S. Constitution, and lead broad social transformation in America (Dodson, 2015). And while all of this is so, before she completed any of this, Justice Ginsburg was known as Professor Ginsburg, spending seventeen years teaching law at two highly respected institutions of higher education. During this time, she created and taught revolutionary courses on Women and the Law, co-write the first-ever published casebook on sex-based discrimination, and contributed broadly to law scholarship and advocacy (Kay, 2015). Though the time Ginsburg spent working in higher education goes largely 
unexamined in comparison to her time spent in judicial offices, her life is forever entwined with education, having been a way-making female law student, a pioneering professor and real-world advocate, and an adjudicator who changed the face of education in the United States. This manuscript will report Ruth Bader Ginsburg's story and give perspective beyond her contributions as judge, focusing on her path to and work as educator.

\section{Early Life}

Joan Ruth Bader was born on March $15^{\text {th }}, 1933$ in Brooklyn, New York City, New York, to Jewish parents Nathan Bader and Celia Bader ("Justice Ruth Bader...”, 1997). Father Nathan Bader worked in a family fur business while mother Celia worked as bookkeeper and secretary, and the two lived a life that at the time was non-traditional, in which wife Celia was a strong partner who advised her husband on the running of his home, business, and other matters (De Hart, 2018). While both parents were kind, attentive, and loving, Celia had a more significant impact

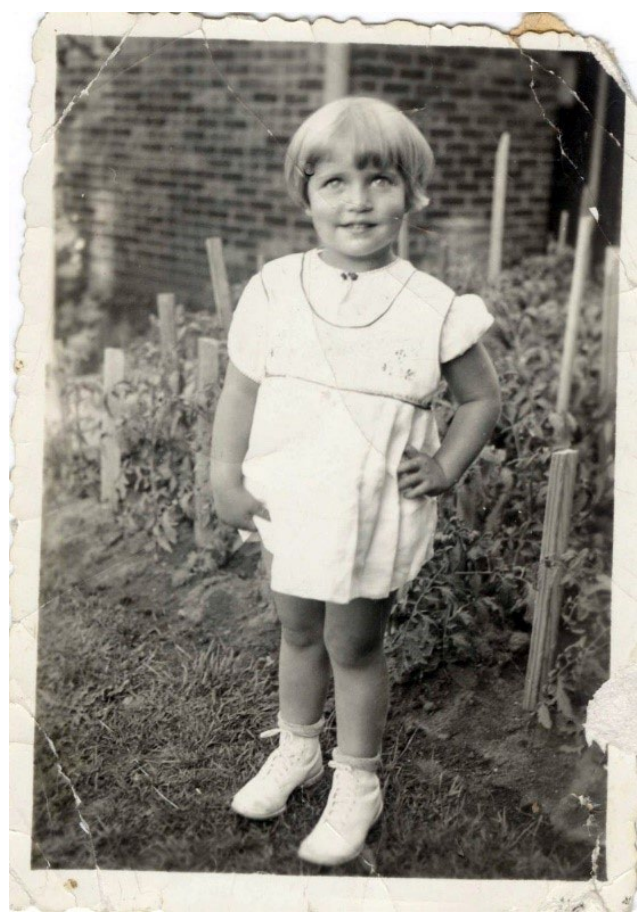
on Joan Ruth's life (the "Joan" would later be dropped). Though Ruth was born the second of two daughters, her older sister died tragically of meningitis in 1934, leaving Ruth to grow up an only child (Dehart, 2018).

Figure 1. Ruth Bader at age two. (2015, February 15). August 2, 1935 Childhood photograph of Ruth Bader taken when she was two years old [digital image]. Retrieved from https:// time.com/3714172/ruthbader-ginsburg-youngphotos/ 
Figure 2. Ruth Bader at age 15. (2015, February 15). 1948 Ruth Bader delivers a sermon as camp Rabbi at the age of 15, at Che-Na-Wah camp in Minerva, N.Y. [digital image]. Retrieved from https://time. com/3714172/ruth-baderginsburg-young-photos/

Celia Bader's life experience had significant effect on her daughter Ruth's path. Celia had been eager to pursue an education, but her plans were cut short because of financial instability in her family and "conventional assumptions about the place of

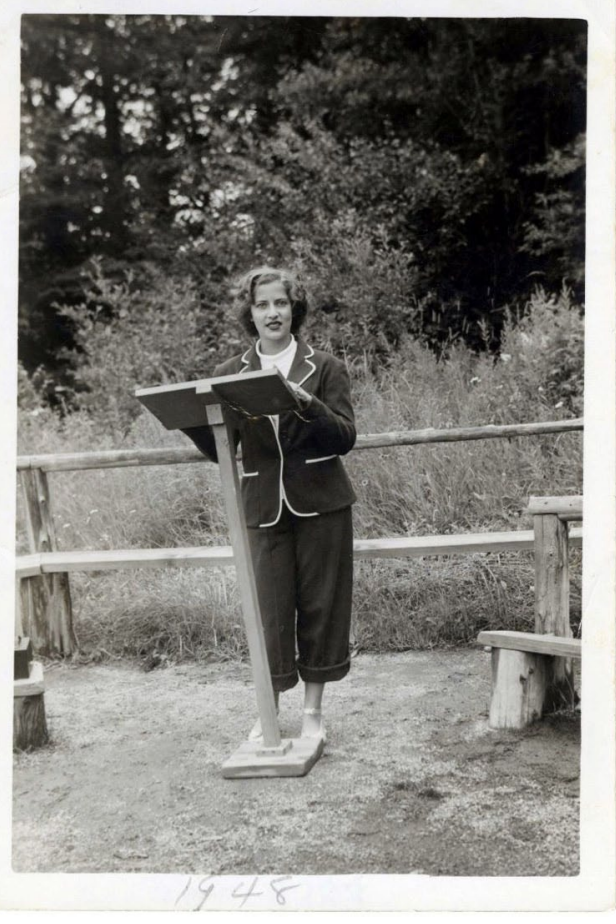
women," especially in traditionally Jewish households, in which the family made sacrifices to support the education of the oldest son at the expense of all other children (De Hart, 2018). Celia Bader was strict but loving and Ruth credits her mother for encouraging her ambition and intellectual development (Kay, 2015). From Celia, Ruth Bader gained her academic orientation and her later obsession with intellectual achievement (De Hart, 2018), which would begin in elementary school and last throughout her life. Early on, Celia bestowed upon her daughter goals of education and independence, having been denied the opportunity to pursue these herself.

During her young life, Ruth Bader was committed to excelling academically and from a young age sought compassion and justice, ideas related to her by her mother through the Jewish "tikkun olam", which means "repairing the world", and exemplified by women leaders and proto-feminists such as Eleanor Roosevelt, Amelia Earhart, Emma Lazarus, Henrietta Szold, and Lillian Wald (De Hart, 2018), whom Celia and Ruth admired. Beyond this, Ruth Bader grew up during war time and the Holocaust, which contributed to her passion for history and support 


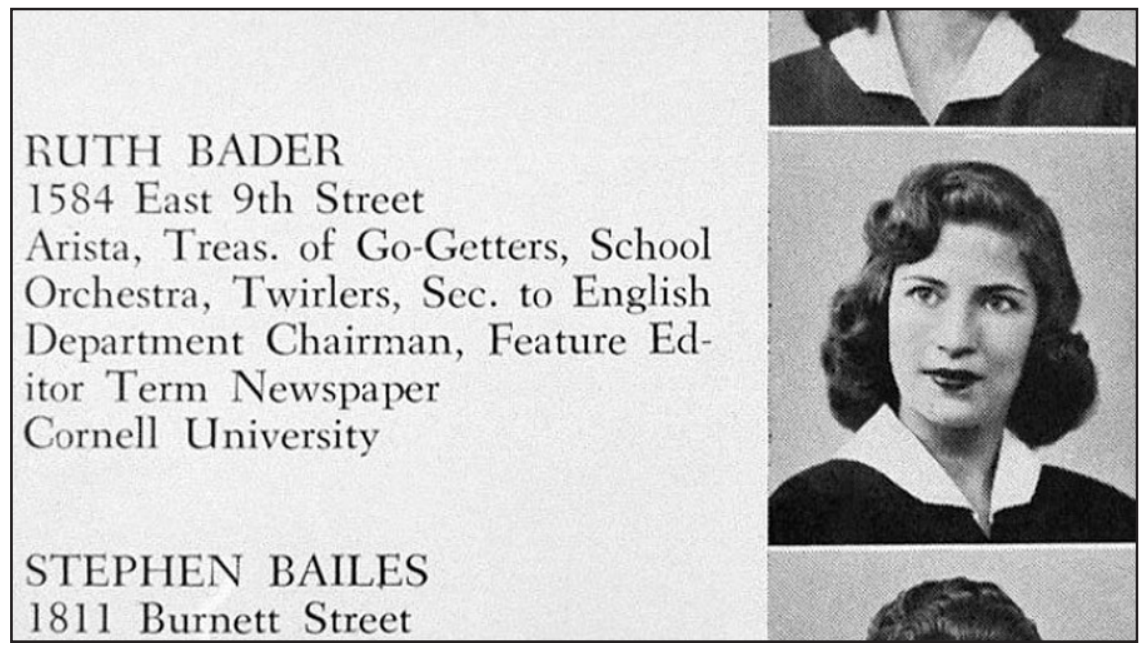

Figure 3. Ruth Bader in her senior year, James Madison High School. From Notorious RBG: The Life and Times of Ruth Bader Ginsburg (pg. 26), by I. Carmon \& S. Knizhnik, 2015, London: Harper Collins Publishers.

for human rights law (Kay, 2009). Ruth described her mother as enabling her in her success early in life because she "made reading a delight and counseled me constantly to 'be independent'” (Ginsburg, 2018, p. Xv). Celia passed away from cervical cancer in the spring of 1950, the same year Ruth graduated high school and left for Cornell University (De Hart, 2018).

\section{Higher Education - Cornell}

Ruth Bader's collegiate experience was rife with examples of the sexbased discrimination she would later oppose and advocate against. As an undergraduate female student at Cornell in the early 1950s, she was required to follow a dress code for women which included skirts as mandatory, grooming according to a collegiate code for women, and regulations on everything from mealtime manners to nighttime curfews (De Hart, 2018). In class, Ruth learned from her professor, famous twentieth-century author Vladimir Nabokov, how to paint with words, while from Robert Cushman, known as an expert on American constitutional 
law and civil liberty, she learned about economy in writing (De Hart, 2018). Says Ginsburg of Nabokov, "Choosing the right word, and the right word order, he illustrated, could make an enormous difference in conveying an image or an idea" (Ginsburg, 2018, p. xv). Professor Cushman would also give Ruth her first work in education, hiring her as an undergraduate research assistant (Ginsburg, 2018).

Other activities Ruth Bader undertook during her undergraduate years included work in the Women's Self-Government Association and a seat on the student-faculty Committee on Academic Conduct for the Liberal Arts College

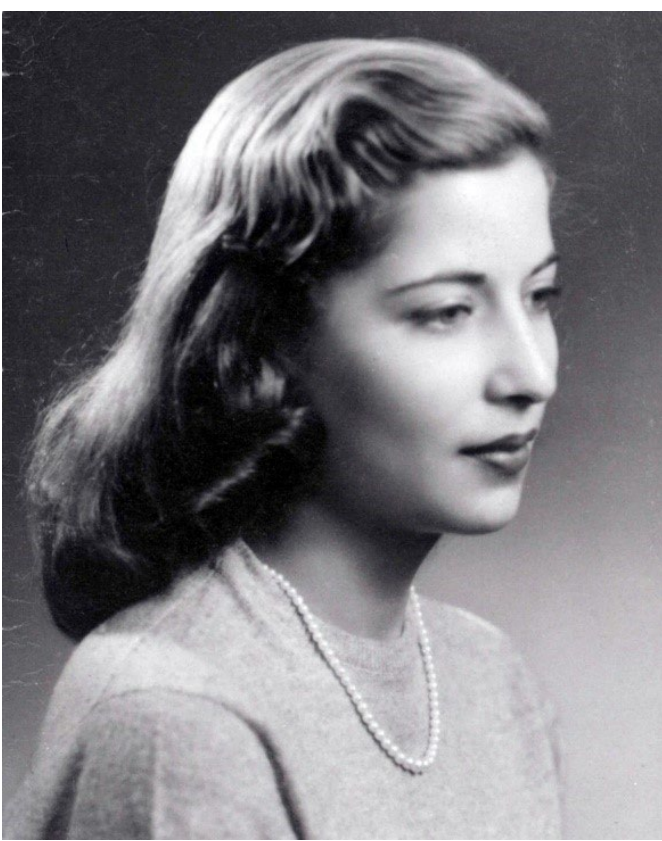

Figure 4. Ruth Bader at Cornell. (2015, February 15). December 1953 Studio photograph of Ruth Bader, taken in Dec. 1953 when she was a Senior at Cornell University. [digital image]. Retrieved from https://time.com/3714172/ ruth-bader-ginsburg-young-photos/ ("Justice Ruth Bader...", 1997). Because of her impressive work in these positions, one of her later letters of recommendation to Harvard Law School included that during this time she proved herself, and that "Miss Bader does not seek leadership or positions of influence; they are thrust upon her because of strength of character and intelligence (De Hart, 2018, p. 54)". During this time Ruth realized she was different from many women of her class: while they focused on meeting a husband over completing their degree (typically pushed upon them by their parents who lived through the war years), she aspired to intellectual development and independence that included the unending search for knowledge and education (De Hart, 2018). 
While at Cornell that Ruth met her future husband Martin "Marty" D. Ginsburg. Ruth's partnership with Marty is often described as a contributing reason for her success both academically and professionally. According to Ruth, "He was the only guy I ever dated who cared whether I had a brain," (De Hart, 2018). Together, Ruth and Marty chose to study law after their undergraduate years, and Marty expressed an enthusiasm for having dual careers, straying wildly from gender norms, that would have been considered progressive at the time. When asked why she chose law over other subjects, Ruth said, "I saw that there were lawyers, brave lawyers, standing up for the people who were called before the Senate Internal Security Committee, the House Un-American Activities Committee. So I thought, well, that's what I would like to do" (Metzger, G., Gluck, A.,

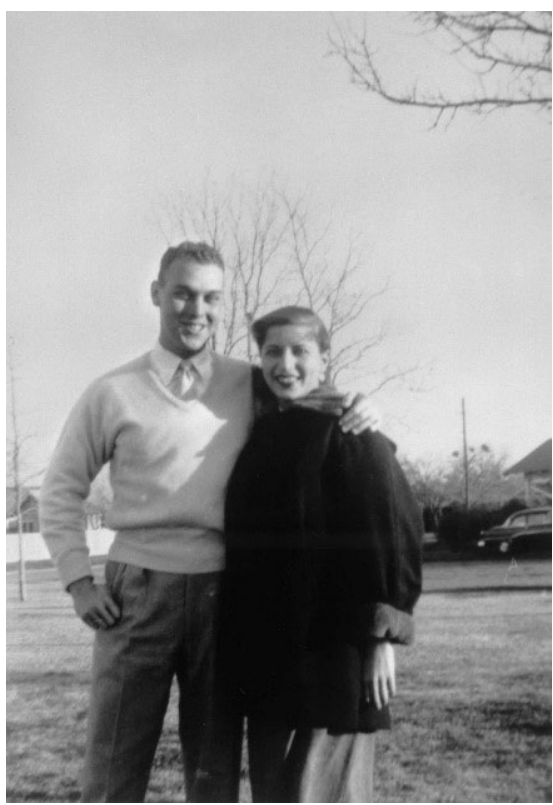

Figure 5 Marty and Ruth. (2015, February 15). Fall, 1954 Martin D. Ginsburg and Ruth Bader Ginsburg taken in the fall while Martin Ginsburg served in the Army. [digital image]. Retrieved from https://time.com/3714172/ ruth-bader-ginsburg-youngphotos/ \& Ginsburg, R.B, 2013, p.7). Ruth graduated first among the women in her class and second overall (Kay, 2015) as College of Arts and Sciences Class Marshall and with high honors in government and distinction in all subjects ("Justice Ruth Bader..., 1997) in 1954.

Marty and Ruth Ginsburg were married on June 23 of that year, had their first child in July 1955, and following Marty's two years in service to the military, moved to attend Harvard together in 1956 (De Hart, 2018). 


\section{Legal Education - Harvard}

"'Why are you at Harvard Law School, taking a place that could have gone to a man?'” (De Hart, 2018, p. 56) asked Dean Erwin Griswold of each of the nine first-year women who began law school with Ruth Bader Ginsburg. Such was the environment when Ruth entered law school. As recently as a few years previous, Harvard had been a men'sonly institution, and in 1954 had no female faculty (De Hart, 2018). The class of 552 students in Ruth's entering year had a representation of only nine women (Kay, 2015).

Gender discrimination existed in many ways while Ruth was at Harvard. The library had separate entrances for each gender, with many materials requisite for adequate legal coursework kept in an area designated as men only (De Hart, 2018). The male cohort gave sexist and derogatory nicknames to their female counterparts, professors called on women as sport or jest, and women were harassed through intimate questioning regarding their opinions on sex-based cases, such as those involving rape (De Hart, 2018). Even using the restroom was hyper-gendered: Langdell Hall where classes were held was not built with a women's facility included.

Despite these challenges, Ruth was a strong student and not deterred from advocating for women in the legal profession when faced with gender discrimination. In Professor Benjamin Kaplan's class, Ruth found her first role model in professorship (Kay, 2015). Kaplan was a master of his field of civil procedure, which Ruth held as a major interest for her entire career and found an example of teaching that engaged students with wit and content while emphasizing precision, craftsmanship, and economy of words (De Hart, 2018). Ginsburg said Kaplan, “... used the Socratic method in his civil procedure class to stimulate, never to wound ... [he] was the model I tried to follow in my own teaching years" (Ginsburg, 2018, p. xv). Along with Kaplan, Ruth relied greatly on her intellection as well as her partnership with Marty to succeed at Harvard while managing her home life. Throughout school Ruth was at the top of her class, a benefit of which was a place on the Harvard Law Review (De Hart, 2018).

Another model for Ruth during this time was professor Albert Sacks, who taught a course on the legal process. Sacks believed in equal 


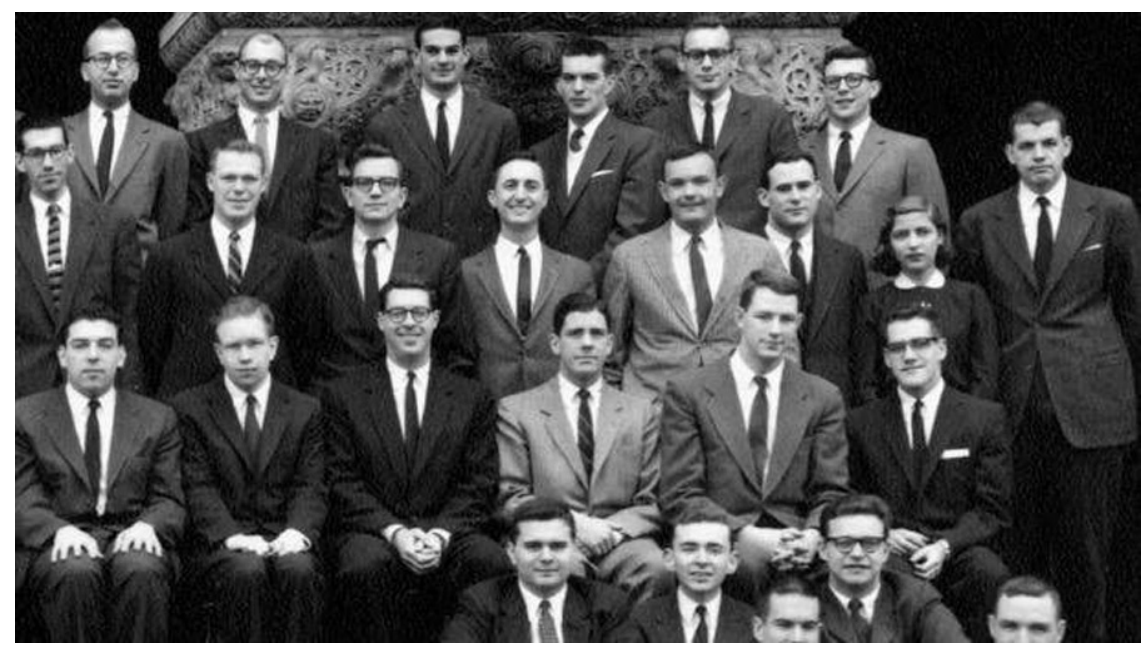

Figure 6. Ruth Bader Ginsburg and the men of the Harvard Law Review, Harvard Law School 1957. From Notorious RBG: The Life and Times of Ruth Bader Ginsburg (pg. 35), by I. Carmon \& S. Knizhnik, 2015, London: Harper Collins Publishers.

opportunity for women and was a kind and patient teacher in ways that many at this time were not (De Hart, 2018). The legal process was another that would remain a major interest of Ruth, wherein she could imagine how the law should be instead of how it was (DeHart 2018).

In 1957, Marty was diagnosed with testicular cancer. While in treatment, Ruth took on more work at home but retained her focus on her schoolwork. Marty's illness also served to fortify Ruth's commitment to work outside the home, as she recognized the importance of not relying on a male counterpart to provide (De Hart 2018). While in treatment, Marty completed his law degree and was recruited to the Manhattan firm of Weil, Gotshal \& Manges, and in the summer of 1958 the Ginsburgs relocated to New York (Kay, 2004).

\section{Legal Education - Columbia}

The challenge of moving to New York was for Ruth to strategize how she would complete her own degree. Ruth appealed to Harvard that 
she be allowed to complete her remaining year at Columbia but receive her degree from the former and was denied because she had not made a strong enough case Ruth had been reluctant to ask for special treatment due to the combination of her husband's diagnosis and job opportunity (De Hart, 2018). Similar requests were often granted to male students (Kay, 2015). Ruth promptly applied to transfer to Columbia.

At Columbia Ruth was again elected to the Law Review and continued to attain academic success (Kay, 2015; De Hart, 2018). According to classmates and professors, Ruth was thoughtful, modest, and fair, and helped Columbia Law Review to produce some of the best issues it had published up to that time (De Hart, 2018). At Columbia

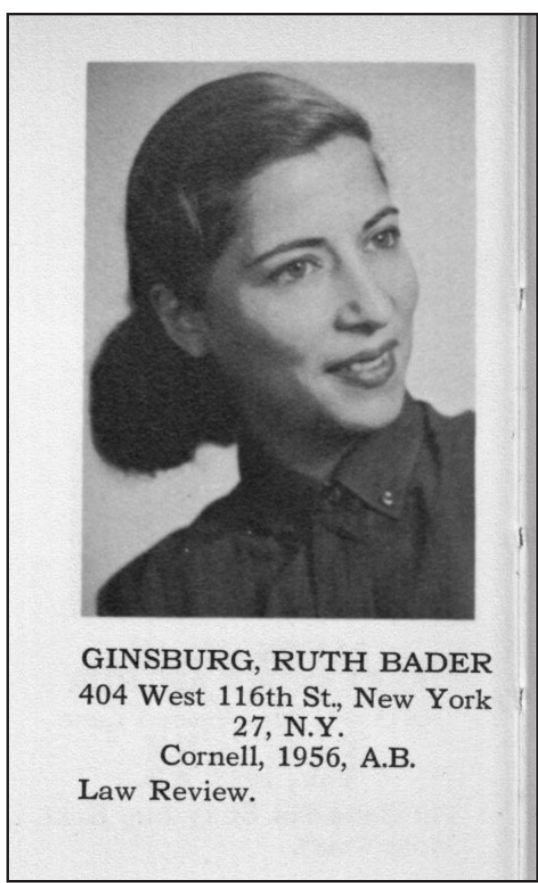

Figure 7. Ruth Bader Ginsburg, Columbia Law School Yearbook 1957. [Digital image] Courtesy Columbia Law Library. Ruth excelled academically, just as she had at Harvard, and "at Columbia, as at Harvard, there were no women law professors who might have served as her role models and mentors" (Kay, 2004, p. 9). Upon graduation in 1959, Ruth was tied for first in her class and was named a Kent scholar, one of five in her graduating class (Kay, 2015).

\section{The Road to Professorship}

At graduation, Ruth should have been immediately offered a job: along with graduating at the top of her class, she had successfully clerked at premier New York law firm Paul, Weiss, Rifkind, Wharton \& Garrison and served on two esteemed law reviews (De Hart, 2018). However, job 
hunting was not easy for her. She interviewed with over a dozen firms and was not offered a second interview or offer, facts attributed to bias and prejudice of the time. Ruth was not only Jewish, but a woman and mother (Kay, 2015). Firms passed over her, citing that she, not they, would be uncomfortable with her presence in the masculine environment of a law firm (De Hart, 2018). In her own opinion, Ruth thought perhaps her temperament of being "rather diffident, modest and shy" did not communicate the strengths inherent in her work ethic and achievement drive (De Hart, 2018). Ruth also said, "When I graduated from Columbia Law School in 1959, not a law firm in the entire city of New York would employ me. I struck out on three grounds: I was Jewish, a woman, and a mother" (Hope, 2014, p. 386).

In the face of these rejections, Columbia professor Gerald Gunther sought to help Ruth find work. He visited with several judges looking to make connections for her, finding again prejudice against Ruth on the basis of her sex (De Hart, 2018). Judge Edmund Palmieri, who eventually would hire Ruth after meeting her and realizing her talents, initially had concerns, citing worries about what his wife and daughters would think of his working long and late hours with a young woman in his office (Kay, 2004).

Ruth worked with Judge Palmieri as a clerk for two years. The two became friends and trusted colleagues and Palmieri later referred to Ruth as one of his best clerks (De Hart, 2018). She could not hold this position forever, however, and following her time there had to seek more work. Professor Albert Sacks of Harvard put forward Ruth's name for additional clerkships, but she again faced rejection. Palmieri also pitched in and finally offers came forward, including an interesting offer to pivot away from clerkship and toward education.

In 1962, Ruth began work with Hans Smit, founder of Columbia Law School's Project on International Procedure (Kay, 2015). Her role with the project was research associate, during which time she would learn Swedish and co-author a book on the Swedish legal system. Ruth spent two years in Sweden with her family, writing the book alongside prominent Swedish appellate judge Anders Bruzelius (De Hart, 2018). The Project on International Procedure offered many professional opportunities to Ruth, including membership on the editorial board of The American Journal of Comparative Law, the Europe Committee of the 
American Bar Association, the board of directors of the American Foreign Law Association, and an honorary degree from Lund University in Sweden (De Hart, 2018). In addition to these benefits, Ruth gained insight from her time living abroad. Sweden had made great progress toward breaking down women's culturally constructed roles and gender-based stereotypes that were harmful to the lives and livelihood of both sexes. Research and policy change lead to role and responsibility reform for men and women to include men's sharing of responsibility in parenthood. As she put it herself, "My eyes were opened up in Sweden... It was already accepted that a family should have two wage earners... The notion that [the husband] should do more than take out the garbage sparked debates that were very interesting to me" (Kay, 2015, p. 16). It was while in Sweden her opinions on sex discrimination began to form: "A Stockholm columnist had just written a much-discussed article asking why the numerous career women should have two roles and men only one" and Ruth described, "I kind of tucked that all away" (Ginsburg, 1978, p. 20). She worked as research associate on the project from 1961 to 1962, and in 1963 served as its associate director ("Justice Ruth Bader...", 1997).

\section{Rutgers: Becoming Professor Ginsburg}

Following her experience abroad, Ruth returned to the United States with a mind that had moved away from the idea of joining a law firm and toward legal scholarship. A questionnaire surveying recent graduate teaching interests at Harvard Law School led to Ruth's being added to a Harvard list of potential faculty (De Hart, 2018). It was shortly after that a professor at Columbia got wind of her interest, and Ruth was invited to fill an opening at Rutgers Law School in Newark, New Jersey (Kay, 2015). The position was recently vacated by the school's only minority faculty member, who taught civil procedure.

In considering the role, Ruth met Eva Hanks, who convinced her to share her CV and other materials for committee submission, after informing Ruth that the Law School's dean, Willard Heckel, was working to diversify the student body (De Hart, 2018). At this time, only eighteen women held tenured academic posts in law schools across the United 
States, and in accepting the tenure-track position, Professor Ginsburg became the nineteenth (Kay, 2015). In taking this role, Ginsburg "was obliged to confront and deal with any misgivings that others - whether colleagues, students, or administrators - may have had about women teaching the law" (Kay, 2004, p. 20).

Despite the left-leaning intentions of Dean Willard Heckel, Professor Ginsburg immediately met discrimination upon hiring. She discovered a significant pay discrepancy between her salary and those of male faculty at Rutgers (Kay, 2004). When she brought this to Heckel, he surprised her by saying the discrimination was justified as she had a husband to help her with the costs of living and maintaining a family, while her male colleagues would have families to support (De Hart, 2018). As Ginsburg put it, " $[\mathrm{He}]$ carefully explained about the state university's limited resources, and then added it was only fair to pay me modestly, because my husband had a very good job" (1995). Though the federal mandate for equal pay had recently been passed, Professor Ginsburg would not confront this issue for some time, waiting until she had moved past the yearly-contracted phase of her employment; she later joined a class-action suit against Rutgers which resulted in enormous salary increases for the women involved (Totenburg, 2015).

At Rutgers, Ginsburg became close with Hanks, the other woman faculty member. Hanks acted as guide and mentor to Ginsburg during these early days in her professorship, advising her on navigating the various political and gender-biased aspects of her new position (De Hart, 2018). Professor Ginsburg began teaching full-time in September 1963, easily settling into her new role. During her first three years in teaching, Ginsburg developed her first scholarly interest, which was in civil procedure, teaching three courses on the subject (Kay, 2004).

Frank Askin, now-retired General Council for the ACLU, recalls arriving to Rutgers Law School on the same day as Ginsburg in 1963, "She as a faculty member, I as a student" (Lee, 2019), Ginsburg teaching the first ever course he had in law school. He describes his experience with her as an inexperienced professor:

She would stand in front of the class and drone on. Most of the students fell asleep, but I was an older student who had been a newspaper report covering politics and the courts. She was 
very knowledgeable but very dull, but because of my background, I was very interested, and would engage with her. Each year the students put on a 'libel play.' They had the student [actor] portraying Ginsburg droning on while being undressed in front of the class, and the portrayer just kept talking. (F. Askin, Personal Communication, November 8, 2019)

In 1965, she again became pregnant, but decided not to disclose this to her employer due to fears of discrimination. Instead, Ginsburg hid her pregnancy with oversized clothes and did not share her news with campus colleagues beyond Hanks, who she trusted (De Hart, 2018). She gave birth to her second child in September 1965 ("Justice Ruth Bader ...", 1997).

In 1966 Ginsburg was promoted to associate professor, teaching two new courses at Rutgers and sitting on the editorial board of The American Journal of Comparative Law (De Hart, 2018). Ginsburg proved a knowledgeable and expert teacher, but in these early years as professor her style of delivery made class difficult for some students. She was no-nonsense and unexpressive, though students did remark she spoke with intensity about the law, a trait that would grow increasingly strong as she moved forward in her career (Kay 2015; De Hart, 2018). During this time Ginsburg began volunteering for the New Jersey affiliate of the ACLU, where she had the opportunity to gain litigation experience she had either been rejected from or passed on earlier in her career path (De Hart, 2018). She also worked to convince the Association of American Law Schools (AALS) to protect female law students from overt discrimination by major law firms, who were commonly overlooked by said firms despite being top-of class and fully capable (Kay, 2015). In continuing her work with AALS, she secured a membership requirement that members of the legal profession provide employment opportunities for female applicants of legal positions, a step toward equal employment rights (Kay, 2015).

Askin was added to the Rutgers faculty upon graduation in 1966 . He describes his experience working with Ginsburg:

I was appointed to the faculty upon graduation, and became the other civil procedure teacher on the faculty. She became my mentor and would guide me in the intricacies of civil 
procedure. She was also one of only two female teachers on the faculty, and when second career women flooded into the law school in the late ' 60 s, they adopted her as their spokesperson and transformed her into a women's rights advocate. (F. Askin, Personal Communication, November 8, 2019)

In 1969 Ginsburg was promoted to full professor with tenure ("Justice Ruth Bader ...", 1997). Immediately following her promotion to tenure, Professor Ginsburg embraced feminism and made bold moves toward becoming a legal activist for women's rights. Moving from civil procedure to the legal status of women was an uncommon reversal of field choice, and was largely due to the influence of her experience in Sweden (Kay, 2015) and the growth in the rights movement in the U.S. The rights movement had been gaining swell over the course of the 1960 s, with sex-based discrimination in the society and in the law adding fuel to the fire. In 1963, the Equal Pay Act was passed. Betty Friedan's The Feminine Mystique was published in the same year and informed and educated women in the middle-class, adding to the movement (1963). In 1964, the Civil Rights Act was passed to give equality in voting, facilities, and employment. Title VII outlawed discrimination on the basis of sex as well as of race ("Civil Rights Act", 1964). In 1970, the New Jersey affiliate of the ACLU invited Ginsburg to join as general counsel. In this role, she was asked to handle "women's" problems fighting cases for women clients against sex-based discrimination (De Hart, 2018). As Ginsburg says, "Complaints from women began trickling into the office, new kinds of complaints... [there was a] growing understanding that the way things had been was not right and should be changed (Metzger et al., 2013, p. 8-9)."

It was at this time Ginsburg began in-depth research of women's legal status, which she found incredibly lacking. She discovered that law maintained a persistence of nineteenth-century ideas about womanhood, especially that the "weaker sex" needed to be "kept safe" (De Hart, 2018). Differential treatment in laws created to safeguard women because of preconceptions and stereotypes of the female gender caused great disadvantage to women. Ginsburg realized that gender discrimination, which she described as "differentiation that combined stereotypical understanding of differences between the sexes with chivalrous 
(and often condescending) attitudes toward 'the ladies' (De Hart, 2018, p. 112)," was pervasive throughout the law and problematic in society. Ginsburg decided to make sex-based discrimination her research specialty. Says Kay of this change in specialty, "Her own personal experience of encountering sex-based obstacles to her progress in the legal profession no doubt also played an important role in her newlyexpressed interest in securing legal equity between men and women" (2004).

Moving away from academics into activism was a bold move for a professor, and especially a woman. During this time, Rutgers faculty had varying views on how to teach the law. Askin continues:

In the late '6os, the Rutgers Law faculty was deeply split between the so-called "academics," who wanted the law school to be another Yale Law only interested in so-called scholarship, and the "activists," who were more interested in diversifying the law school body and promoting clinical education to train students to represent ideological causes and fight for equal opportunity. Ruth always sided with the "activists". (F. Askin, Personal Communication, November 8, 2019)

In 1970 a group of women at Rutgers Law School decided to establish a new journal called the Women's Rights Law Reporter (WRLR) (Langer, 2009). Elizabeth Langer, a former Rutgers Law School student, was one of the founding group, who expressed:

To mediate my entry into law school, still a male dominion notwithstanding our twenty percent female class, I sought out a women's consciousness raising group in Newark... The notion of a legal journal focused on women's rights and women's issues was a novel and fairly radical idea at the time (Langer, 2009, p. 599)

The group was told by Rutgers that WRLR would need to be self-funded, negotiate for office space, and have a faculty advisor acceptable to the dean. That faculty advisor turned out to be Professor Ruth Bader Ginsburg. Langer shared: 
Actually I was rather surprised she said yes. At that point she hadn't been doing women's rights. She was just sort of thinking about it and gearing up, I think to teach a seminar. But I heard she had an interest in women's rights. There were four women teachers at Rutgers Law School in a sea of men, two on the tenure track faculty and two who were in the clinical program. The dean Jim Paul said we needed a faculty advisor in order to bring it to Rutgers and we needed to find our own room to work in, our own space, and we needed to find our own funding.

There were a lot of women who were very interested in informing this Law Reporter and bringing it to Rutgers. We worked together as a team, and Ruth was very involved in the workings of the Reporter. She wrote for it, she submitted articles for it, she helped us with our relationship with the school administration when problems arose. (E. Langer, Personal Communication, October 24, 2019)

It was a risky decision for Ginsburg to advise the Reporter, as she had not yet received tenure.

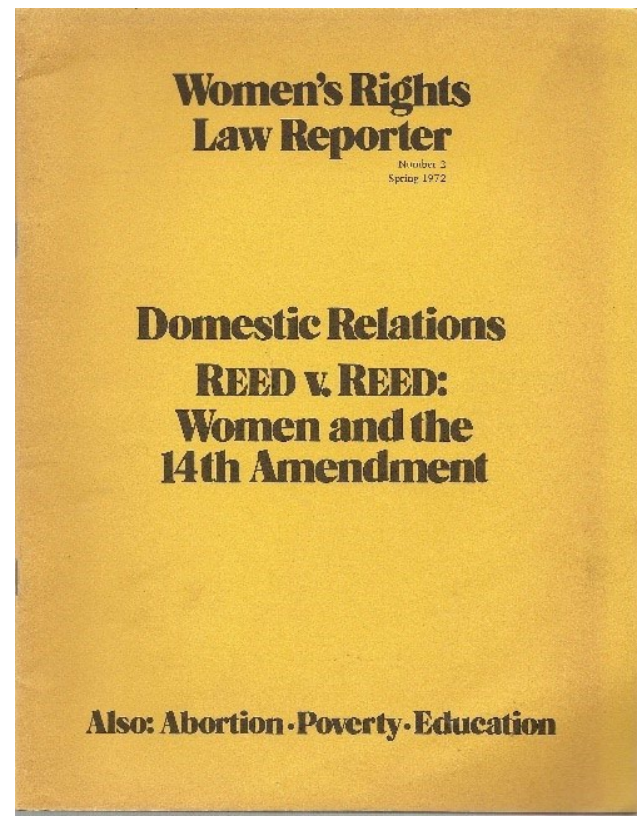
However, Professor Ginsburg readily agreed to support the publication. Ginsburg's contributions included writing, editing, staff counseling, and meeting attendance (Langer, 2009). The students working

Figure 8. Issue 2 of the Women's Rights Law Reporter, 1972. (1972) [digital image]. Retrieved from https://www. amazon.com/Womens-RightsReporter-Domestic-Relations/ dp/Bo04E75SgI 
on the Reporter built lasting relationships with her. Langer describes working with Ginsburg:

She was very demanding. She was a stickler for form, the citations had to be just right, the work had to be top quality, and I was very impressed with her standards and her devotion. She really cared about it. She's very, very smart - we all know that now... She was a very hard worker, she had all her citations, she knew her cases, and she had her theories. It was delightful to be associated with someone who was as focused. She was very focused on her work. I was looking for role models at that age and certainly she was a role model in many ways. (E. Langer, Personal Communication, October 24, 2019)

Elizabeth Langer went on to serve as a Legislative Assistant for Congresswoman Bella S. Abzug (Dem. NY) in charge of domestic affairs including women's issues, Watergate, privacy and freedom of information, serve as a Trial Attorney with the US Department of Justice, litigating federal cases in the US Districts Courts, Courts of Appeals and US Claims Court, and opened a private practice of law in Washington D.C. (Langer, 2009).

Professor Ginsburg proposed a new course, “Women's Rights: Sex Discrimination and the Law", for addition to Rutgers in 1970. At the time, however, there was no casebook for student use. As Ginsburg describes it:

Around 1970, women students whose conscience had awakened at least as much as mine, women encouraged by a vibrant moment for racial equality, asked for a seminar on Women and the Law. I repaired to the Library. There, in the space of a month, I read every federal decision ever published involving women's legal status, and every law review article. That was no grand feat. There were not many decisions and not much in the way of commentary. Probably less altogether than today accumulates in six months' time. (1995) 
Several other law professors had gotten the same notion to create courses at NYU, Yale, Georgetown University, George Washington University, SUNY Buffalo, and the University of New Mexico (De Hart, 2018). These professors created their courses by trading syllabi, readings, and assignments, creating the material that would later define the field of Women and the Law. Ginsburg argued that universities were late in regard to this course offering, saying that course offerings related to sex roles existed in dozens of institutions of higher education, but in less than ten law schools (Ginsburg, 1971). Beyond this, Ginsburg felt law schools had an obligation to women in updating standards of practice, including "the elimination from law school texts and classroom presentations of attempts at comic relief via stereotyped characterizations of women [and] the infusion into standard curricular offerings of material on sex-based discrimination" (Ginsburg, 1971, p. 481). She first taught a course titled Women's Rights: Sex Discrimination and the Law at Rutgers in 1970-71, and then again in 1971-1972 (Kay, 2004).

In 1970, Melvin Wulf, legal director of the national office of the ACLU, proposed a special project on women's rights to Ginsburg. She used this as an opportunity to begin taking some of her most famous cases, including Moritz v. Commissioner of Internal Revenue and Reed $v$. Reed. Following these cases, Wulf proposed the ACLU's Women's Rights Project, of which he wished Ginsburg to be director, which she accepted.

At the same time, the Nixon administration extended affirmative action to universities, meaning any business with over $\$ 50,000$ had to formulate affirmative-action plans for hiring minorities and women (Graham, 1992). Not only was it against AALS member requirements to offer positions to women, now it was illegal under federal law. Law schools across the country began seeking increased numbers of female faculty, and Ginsburg met with several institutions, including Harvard, where she has been described as, "Perhaps the most famous woman to teach temporarily at Harvard Law School" (Basile, 2015, p. 144), before deciding on Columbia (Kay, 2015). 


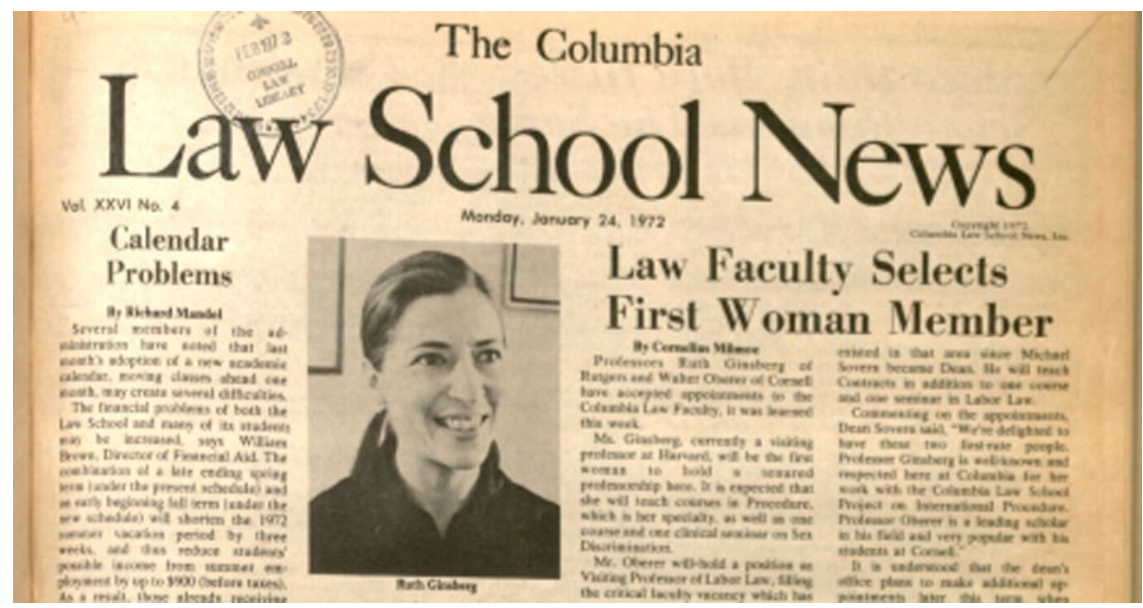

Figure 9. Ruth Bader Ginsburg, Columbia Law School News (1972). Courtesy Columbia Law Library.

\section{Professor Ginsburg at Columbia}

In January of 1972, Columbia Law School announced its hire of Professor Ruth Bader Ginsburg (Kay, 2015). In her courses, she taught with authority, command, and expertise. Shortly after joining, Ginsburg got wind of a problem at Columbia - in accordance with budget-related labor cuts, staff had been dismissed: twenty-five maids (women), but no janitors (men) (Kay, 2004). Ginsburg was finishing her year at Rutgers but looked into the issue, working out the problem through legal avenues using equal employment practices and acting as both professor and real-life advocate. In the end, no maids were dismissed. Later, she would also join a class action lawsuit against the university for pension disparity between male and female faculty (Totenburg, 2015).

Jim Rogers was a student of Professor Ginsburg's during her time at Columbia when he was a first-year law student. He describes her teaching style during their civil procedure course together:

It was a very large class, 150 of us in one class. She made it very alive and lively, which is interesting because I was not interested in litigation myself, so why did I have to know civil 
procedure? But it was a great class, and I did very well in it, because she made it interesting.

In class one day one of the classmates I was sitting next to said, 'You know, she just argued a case before the Supreme Court this week.' ... I went up to her after class, which is something I didn't do very often, with her or anybody. I was a little bit shy. And I remember how interesting it was, I didn't know what the case was or anything. I knew she had argued a case and for whatever reason I thought that was super interesting. I said, 'I understand you argued a case before the Supreme Court this week' and her face just lit up, as if nobody in the world had ever cared about this or cared enough to ask her about this. ... Her experience as an actual litigator really informed how she taught. (J. Rogers, Personal Communication, October 29, 2019)

According to Rogers, she had a unique way of thinking about the law, and so had an interesting perspective in teaching. He describes her teaching a class about Civil Procedure Rule 12B, which had at the time seven bases to dismiss:

"She said, 'I just filed a motion. Under 12, but not any other particular subsection, because the rule is not exclusive. It lists seven bases, but it doesn't say those are the only ones. I filed a motion saying to dismiss this case... based on the larger principle.' So she was saying we need to think creatively and not be confined to a specific way of thinking about something. At the same time you have to be reading the rules or the law very carefully because if rule 12B had said these are the only seven bases, it would be hard to be creative. I think that was a great life lesson.

To some extent, that's the hallmark of a great lawyer versus a good lawyer. A good lawyer can spot the issues and figure out, 'What is the law, what's out there already, and how does this fit?' But the great ones, and she is certainly one, they say, 'Well, how should this fit? What ways should we be thinking about this? Has it been thought about in this way before? (J. Rogers, Personal Communication, October 29, 2019)

After graduation, Jim Rogers spent 28 years in private practice before transitioning to a career as in-house counsel for varying lengths of time of Orbitz, Expedia, and Cars.com. 


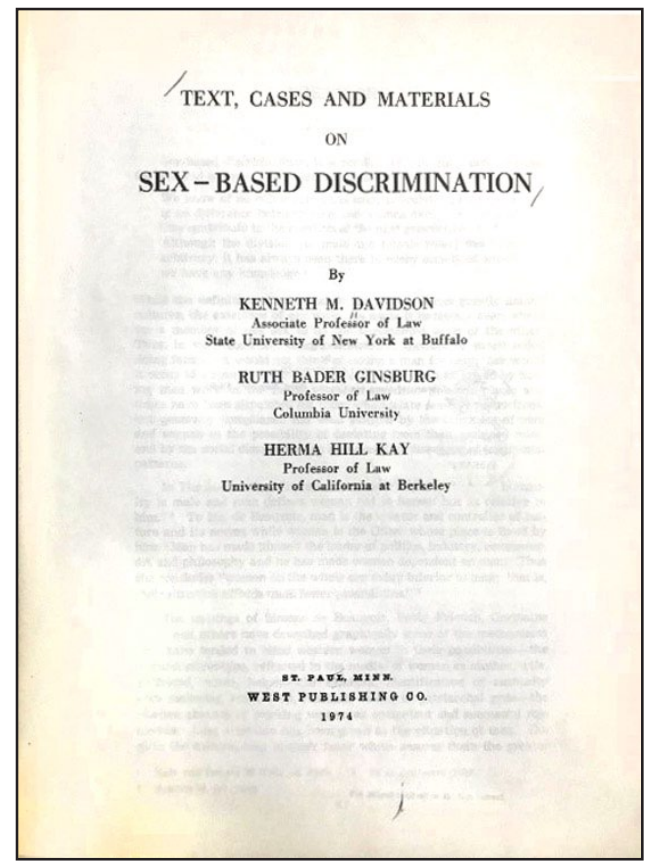

Figure 10 Cover Page of Casebook on Sex-Based Discrimination (1974) Text, Cases and Materials on Sex-Based Discrimination [digital image] (Davidson, K., Ginsburg, R. \& Kay, H., 1974).

In 1972, Professor Ginsburg met with colleagues Kenneth Davidson of SUNY Buffalo and Herma Hill Kay of Berkeley to create a casebook for the many Women and the Law courses that had continued to appear across the U.S.: "[Davidson and I] both agreed that the projected casebook would need the collaboration of an expert on constitutional Law. Both of thought of Ruth Bader Ginsburg" (Kay, 2013, p. 55). The first edition of the book was published in 1974 and was created to exist for stand-alone courses on what would from then on be called Sex-Based Discrimination instead of Women and the Law (Kay, 2015). Ginsburg contributed as co-author as well as through her continuing casework as a litigator for the ACLU Women's Project, as her cases were commonly included in the first and also later editions (Kay 2015).

The effect of this casebook was broad, with reviewers concluding that its existence alone did much to legitimize the study of sex-based discrimination and to create accessibility for its spread (Kay, 2013). The casebook remains in print and is in its seventh edition. During all eight years of her time at Columbia, Ginsburg offered her course on Women's 


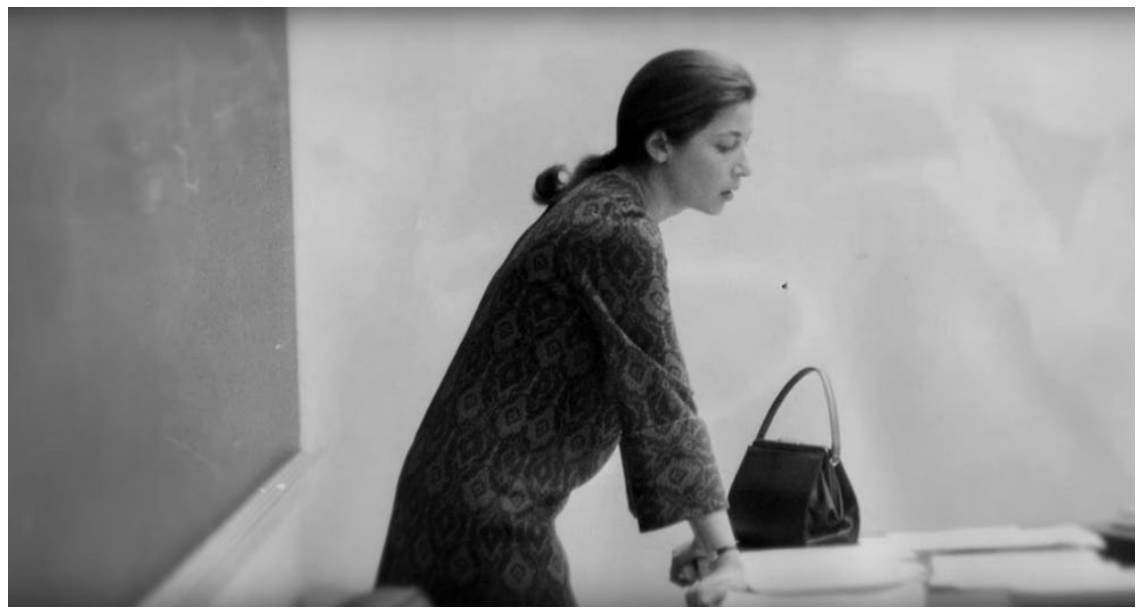

Figure 11. Ruth Bader Ginsburg at Columbia Law School, (n.d.). Courtesy Columbia Law Library.

Rights: Sex Discrimination and the Law, and used the casebook she coauthored to teach the course from the time of its first publication (Kay, 2004).

Professor Ginsburg taught at Columbia from 1972 - 1980 ("Justice Ruth Bader ...”, 1997). During this time, she worked as feminist, advocate, and remained at the ACLU, arguing the cases Struck v. Secretary of Defense and Frontiero v. Richardson (Kerber, 2015). She describes her work during this time as "on three fronts: we sought to advance, simultaneously, public understanding, legislative change, and change in judicial doctrine" (Ginsburg, 2002, p. 1441). Also during this time, the number of women enrolled in law schools across the country increased dramatically: "Women in the first-year law class jumped from 8 percent in the class of 1970 to 20 percent in $1972-73$ and then to 32 percent by 1980" (De Hart, 2018, p. 227). These women flocked to the female professors at Columbia, admiring their balance of work, home life, femininity, and family. Students described her as extremely knowledgeable, highly analytical, and in sex-discrimination matters, passionate about "litigation strategy, timing, [knowledge] ... and precision (De Hart, 2018, p. 227)”. Women were drawn to Professor Ginsburg and also saw her as a role model. 
Monica Wagner, a student of Ginsburg's from this time who currently does environmental litigation for the New York Attorney General, describes working with her while at Columbia:

When I was a first-year law student at Columbia and she was a professor there, I stopped by her office to ask whether she would allow me to take her sex discrimination clinic in my second year even though it was normally open only to thirdyear students. She said no but the following summer I received a note from her asking whether I would be interested in being her research assistant. I had known of her pioneering work in women's rights before I came to Columbia so I was thrilled to receive her offer and immediately accepted. I was her research assistant until President Carter appointed her to the U.S. Court of Appeals for the District of Columbia Circuit in the spring of 1980. (M. Wagner, Personal Communication, November 20, 2019)

While at Columbia, Ginsburg worked to solidify the Equal Protection Clause into the Equal Rights Amendment (ERA), a would-be new Amendment to the Constitution (Kay, 2015). In speeches, manuscripts, and law review articles she argued that to achieve gender equality ratification of the ERA was essential, and that doing so would eliminate most gender-based classifications, helping create a system of gender neutrality (Morris, 2002). Following its failure in 1982, Ginsburg was not only skeptical of the decision but critical (Kay, 2015).

In 1979, Ginsburg was ready for a career move out of law education and into judgeship. It was described that:

Ruth held a special place at the Law School. She gained national renown for work in gender discrimination, which in itself made her presence at Columbia invaluable. In addition, her clear, cogent scholarship earned her the respect of scholars in such traditional fields as conflicts and civil procedure. (Sofaer, 1984, p. 843) 


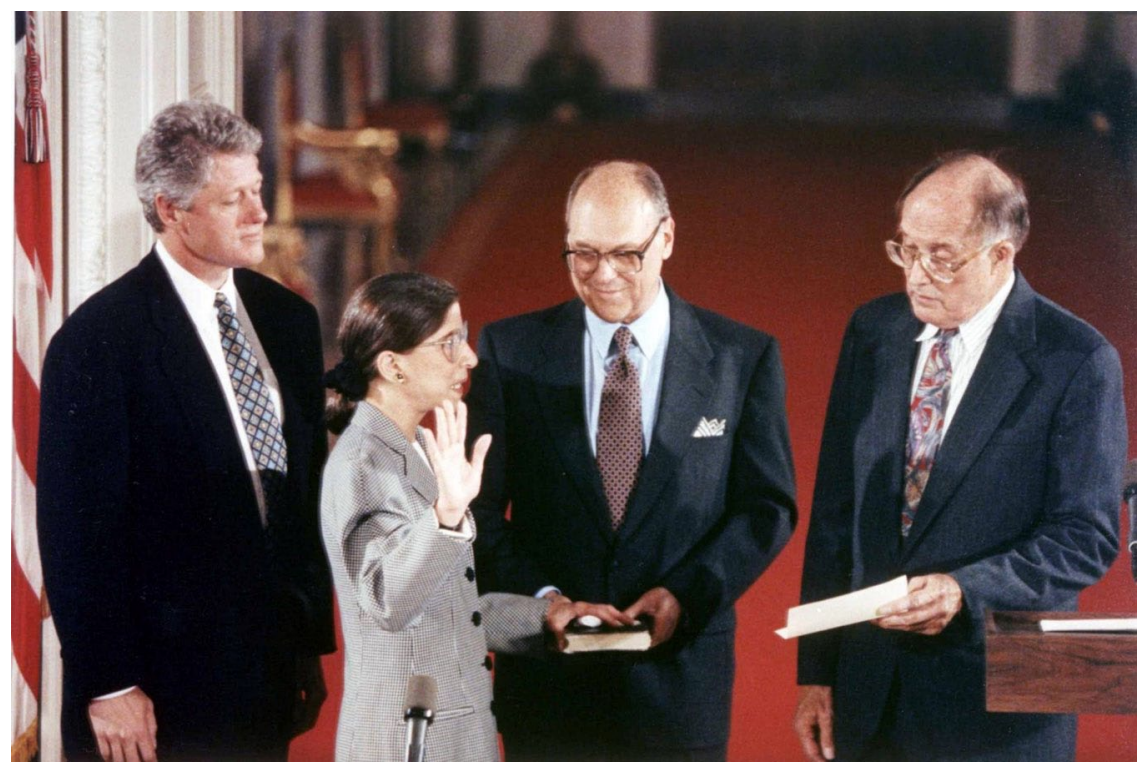

Figure 12. Ruth Bader Ginsburg is sworn in as Supreme Court Justice, Photo Courtesy of TIME Magazine. (2015, February 15). August 10, 1993 Justice Ruth Bader Ginsburg is sworn in as an Associate Justice of the Supreme Court [digital image]. Retrieved from https://time.com/3714172/ ruth-bader-ginsburg-young-photos/

\section{Professor as Judge and Justice}

Beginning in 1979, she worked to gain appointment to the D.C. Circuit in the U.S. Court of Appeals, which she accomplished in late 1980 (De Hart, 2018). She spent thirteen years on the Court of Appeals, writing 353 majority opinions, 21 concurring opinions, and 17 dissenting opinions (Morris, 2002). In June 1993, it was announced that President Bill Clinton has selected Judge Ginsburg to fill a seat left open by retiring Justice Byron R. White (Morris, 2002).

As Justice, Ginsburg used skills learned and honed as a professor in her opinions. She was well-researched and knew her fields, Civil Procedure and Sex-Based Discrimination, with a high level of scholarly expertise (Kay, 2015). In arguing her positions, Ginsburg has been described as "like a patient classroom teacher justifying her reasoning 
to a doubting student (Kay, 2015, p. 28)". She acts as professor to the world, always clarifying patiently and thoroughly while litigating (Kerber, 2015, 40). She is also said to use both of her experiences in her work, clarifying the law as Justice and then putting those decisions in context as Professor. In describing the effect being a professor had on her, she Ginsburg shares, "My writing style tends to be, some people think, more bland. I'm not as immediately attention-grabbing. But I hope what I write has staying power (Metzger, 2013, p. 27)." She was described by Kay as, "... establishing a solid reputation for the painstaking accuracy of her work, the intellectual depth of her legal concepts, and the strength and clarity of her vision of women's rights as human's rights" (2004, p. 20).

Throughout her life, Justice Ginsburg has used her position to make continuing positive impacts on her students' lives. In 1989 Elizabeth Langer, with whom Ginsburg had worked on the Women's Rights Law Reporter at Rutgers, agreed to represent a woman whose case would be taken to the Court of Appeals for the District of Columbia Circuit (Langer, 2009). As Langer puts it:

I was elated to find our WRLR advisor, the Honorable Ruth Bader Ginsburg, sitting on the appellate panel. Judge Ginsburg easily grasped the significant of the case ... Judge Ginsburg's opinion helped my client gain the self-confidence and empowerment that often accompanies a civil suit for sexual assault. (Langer, 2009, p. 606)

She continues,

"When she came to Washington her husband joined the faculty of Georgetown Law School where my husband was working. So we maintained a close relationship with them in the years since" (E. Langer, Personal Communication, October 24, 2019).

Former student Rogers also felt lasting effects of his relationship with Justice Ginsburg in his time at law school: 
She was nominated to the D.C. Circuit. And I wrote a letter saying, you know, congratulations for being nominated, I'm having a great time clerking, and I would love to come on as one of your first clerks. And I became one of her first clerks. ...She had said there were three clerks... she said this will be good because you've been a clerk for years, you can give me guidance on how a judge should operate here. And I just had to chuckle, because inside of a week, she knew exactly how she was going to operate.

One thing common to both [my time with her as professor and in clerkship under her] was the caring touch. She was very close to her clerks, she cared about us personally. We had dinner at her house, not infrequently, because as you know Marty was a fabulous cook. ... She threw an engagement part for [me and my fiancé] at her apartment. And we invited, you know, 50 people to her place ... at Watergate. (J. Rogers, Personal Communication, October 29, 2019)

This type of long-lasting relationship and influence from Ginsburg on her students seems common. Wagner describes it:

I went to law school with a commitment to doing public interest law so that was more of a commitment that we both shared rather than a path she inspired. What I appreciate the most about our friendship is all the support she has given to me for that path over the past several decades. From time to time she sends me an affectionate note saying that the work I do is important and that she can see how I'm happy I am doing it. Needless to say those notes are very precious to me. (M. Wagner, Personal Communication, November 12, 2019)

\section{Conclusion}

Ruth Bader Ginsburg's life has been one of not only great judicial and political inspiration, but of achievement for education. Through her scholarly excellence and drive, she helped in making the way for women 
to study the law. Through her resiliency, she moved past gender bias and stereotypes to be one of the first few women to teach the law. And through a melding of scholarship and classroom teaching that included experiences from real-world advocacy, she created lasting impressions on her students and on the field of law scholarship. Her life and leadership have had a lasting impact on the people in her life, such as her former students from seventeen years of teaching law and continue to do so in the present day.

\section{References}

Annual Survey of American Law (1997). Justice Ruth Bader Ginsburg. Annual Survey of American Law, 1997, xxxix-xlii.

Carmon, I., \& Knizhnik, S. (2015). Notorious RBG: The Life and Times of Ruth Bader Ginsburg. London: HarperCollins Publishers.

Civil Rights Act of 1964, Pub.L. 88-352, 78 Stat. 241 (1964).

De Hart, J. S. (2018). Ruth Bader Ginsburg: a life. New York, NY: Alfred A. Knopf.

Friedan, Betty. (1963). The Feminine Mystique. New York: Norton.

Ginsburg, R. (1978). Equal Rights Amendment Is the Way. Harvard Women's Law Journal 1, 19-26.

Ginsburg, R. B. (2018). My Own Words. New York, NY: Simon \& Schuster.

Ginsburg, R. B. (1995). Remarks for Rutgers. Columbia Law Review.

Ginsburg, R. B. (2002). Remarks for the Celebration of 75 Years of Women's Enrollment at Columbia Law School October 19, 2002. Columbia Law Review, 102(6), 1441-1448. doi:10.2307/1123788

Ginsburg, R. B. (1971). Treatment of women by the law: Awakening consciousness in the law schools. Valparaiso University Law Review, 5(2), 480-488.

Graham, H. D. (1992). Civil rights and the presidency: race and gender in American politics, 1960-1972. Oxford University Press.

Hope, J. (2004). The Women of 1964: Paving the Way. Harvard Women's Law Journal, 27, 381-386.

Kay, H. H. (2013). Claiming space in the law school curriculum: casebook on sex-based discrimination. Columbia Journal of Gender and Law, 25(1), 54-62. 
Kay, H. H. (2015). Ruth Bader Ginsburg: Professor Extraordinaire. In S. Dodson (Ed.), The Legacy of Ruth Bader Ginsburg (pp. 12-30). New York: Cambridge University Press.

Kay, H. (2004). Ruth Bader Ginsburg, Professor of Law. Columbia Law Review, 104(1), 2-20.

Kerber, L. K. (2015). Before Frontiero The Was Reed. In S. Dodson (Ed.), The Legacy of Ruth Bader Ginsburg (pp. 31-43). New York: Cambridge University Press.

Langer, E. (2009). Seizing the Moments: The Beginnings of the Women's Rights Law Reporter and a Personal Journey. Women's Rights Law Reporter, 30, 592-608.

Lee, M. (2019, September). The Ruth Bader Ginsburg I Know. The Village Voice.

Metzger, G., Gluck, A., \& Ginsburg, R.B. (2013). Conversation with Justice Ruth Bader Ginsburg. Columbia Journal of Gender and Law, 25(1), 6-29.

Morris, M. K. (2002). Ruth Bader Ginsburg and Gender Equality: A Reassessment of Her Contribution. Cardozo Women's Law Journal, 9(1), 1-26.

Sofaer, A. (1984). Dean Rosenthal's Commitment to a Strong Faculty. Columbia Law Review, 84(4), 843-845. doi:10.2307/1122382

Totenburg, N. (2015). Notes on a Life. In S. Dodson (Ed.), The Legacy of Ruth Bader Ginsburg (pp. 3-11). New York: Cambridge University Press. 